\title{
Record of New Tapeworm, Lytocestus Alii n.sp. from Freshwater Fish Clarias batrachus, (Bleeker, 1862) at Amravati, Maharashtra, India
}

\author{
Sawarkar B. W. (Corresponding Author) \\ Department of Zoology, \\ G. S. Science, Arts and Commerce College, Khamgaon Dist. Buldana 444 312(M.S.) \\ E-mail: gokulbkale@gmail.com
}

Received: August 1, 2012 Accepted: August 15, 2012

doi:10.5296/jbls.v3i1.2178 URL: http://dx.doi.org/10.5296/jbls.v3i1.2178

\begin{abstract}
Nine specimens of the cestode parasites were recovered from the intestine of Clarias batrachus at Amravati, in the month of March, 1984. They were stained in Borax carmine, whole mount and histological slides of the worm were prepared for detail studies. The mature flattened specimens were long, cylindrical and measure 4.805 in length and 0.674-1.484 in breadth. Morphology and anatomy of the worm is fully discussed in this paper.
\end{abstract}

Keywords: Fish parasite infection, Helminthes, New Tapeworm Lytocestus alii n.sp. Morphology, Anatomy, Clarias batrachus, Amravati, India

\section{Introduction}

The genus Lytocestus was introduced by Cohn (1908), with its type species L. adhaerens found in Clarias fuscus in Hong Kong. This genus was first confirmed by Woodland (1926), who included four more species, in addition to the type species, they are L. filiformis Woodland (1923) Mormyrus caschive. Egyptian Sudan, L. chalmersius, Fuhrmann and Baer (1925), and L. Moghe (1925) (Syn, caryophyllaeus indicus) from Clarias batrachus in India. The same species was recorded by Mehra (1930) from Clarias magus in India and Ramdevi (1973) from Clarias batrachus in India. Hunter (1927) placed the genus in sub-family of his own namely. Lytocestinae and retained only three species L. adhaerens. L. filiformis and L. indicus. He put the species L. cunningtoni and L. chalmersius in the genus Monobothrioides. Subsequent workers, Yamaguti (1959), Gupta (1961), Murhar (1963) have adhered to these changes. Wardle and McLeod (1952) followed Hunter's classification but raised the status of 
Lytocestinae from subfamily to a family. Wardle, Mcleod and Radinovsky (1974) suggested new system of classification of cestodes, which used the term cotyloda as a class and the order Caryophyllidea is kept in this class. Mackiewicz (1962) after examination of original material of L. alestesi, Lynsdale (1956) concluded that it should be considered a synonym of L. filiformis.Ramadevi (1973) described L. longicollis from Clarias batrachus in India. All the seven species came from East Asian countries. Shinde and Deshmukh (1980) redescribed two species of the genus Lytocestus.

Later on Shinde and Phad, 1988 erected L. marathwadensis from Clarias batrachus. Jadhav and Gavhane, 1991 added L.alii and L. clariasae from Clarias batrachus. L. naldurgensis erected by Kadam et.al, 1998 in Clarias batrachus. L. teranaensis was erected in 1999 by Kolpuke and Shinde from Wallago attu. D.N. Patil and B.V. Jadhav, 2002 added L. govindae from Clarias batrachus. In 2002, Pawar and Shinde added L. batrachusae from Clarias batrachus. Later on 2004, L.shindei was erected by Khadap et al., from Clarias batrachus. Tandom et al., 2005 erected four new species L.clariae, L. allenuateus, and L. assamensis in Clarias batrachus and L.heteropneustii in Heteropneusteus fossils. Recently Poonam, 2007 added L. mujumdari from Clarias batrachus. Recently, Sawarkar and Kale (2012), reported new tapeworm Lytocestus thapari n.sp. from a freshwater fish Clarias batrachus, (Bleeker, 1862) at Aurangabad, Maharashtra, India.

\section{Description}

Nine specimens of the cestode parasites were recovered from the intestine of Clarias batrachus Bleeker, 1862, at Amravati, in the month of March, 1984. They were stained in Borax carmine, the whole mounts and histological slides were prepared for anatomical studies. The mature flattened specimens are long, cylindrical and measure 4.805 in length and $0.674-1.484$ in breadth. The head is anterior and is bluntly oval remarkably narrower than the body, the testes are numerous,580-590 in number, preovarian, scattered in the central medullary region of the worm arranged 9-11 rows, in a single field, evenly distributed, oval in shape and measure 0.053/0.022 to $0.121 / 0.083$ in length and breadth (Fig.1.A,B and C). The cirrus pouch is oval, transversely placed and measures $0.833 / 0.1473-0.196$ in length and breadth. The cirrus is thin, coiled inside the cirrus pouch and measures $0.0318 / 0.015-0.022$ in length and breadth. The measures $0.469 / 0.015-0.030$ in length and measures $0.22 / 0.015$ in length and breadth (all measurements are in micron i.e. $\mu$ ).

The ovary is bilobed, having loose masses of two lobes, each connected by isthmus, the ovarian follicles are numerous (32-39 in number), situated near the posterior region of the worm. Right lobe is having 4-5 rows of ovarian follicles and the left lobe is having 8 rows of ovarian follicles. It measures $0.037 / 0.030$ to $0.090 / 0.030-0.045$ in length and breadth. The vagina is curved, coiled tube, starts from genital pore, runs posteriorly in the middle and opens in to the ootype. It measures 1.136 in length and 0.015 in breadth. The vagina dilates almost in anterior one third part, to from spindle-shaped receptaculum seminis, which measures $0.386 / 0.053-0.058$ in length and breadth. 


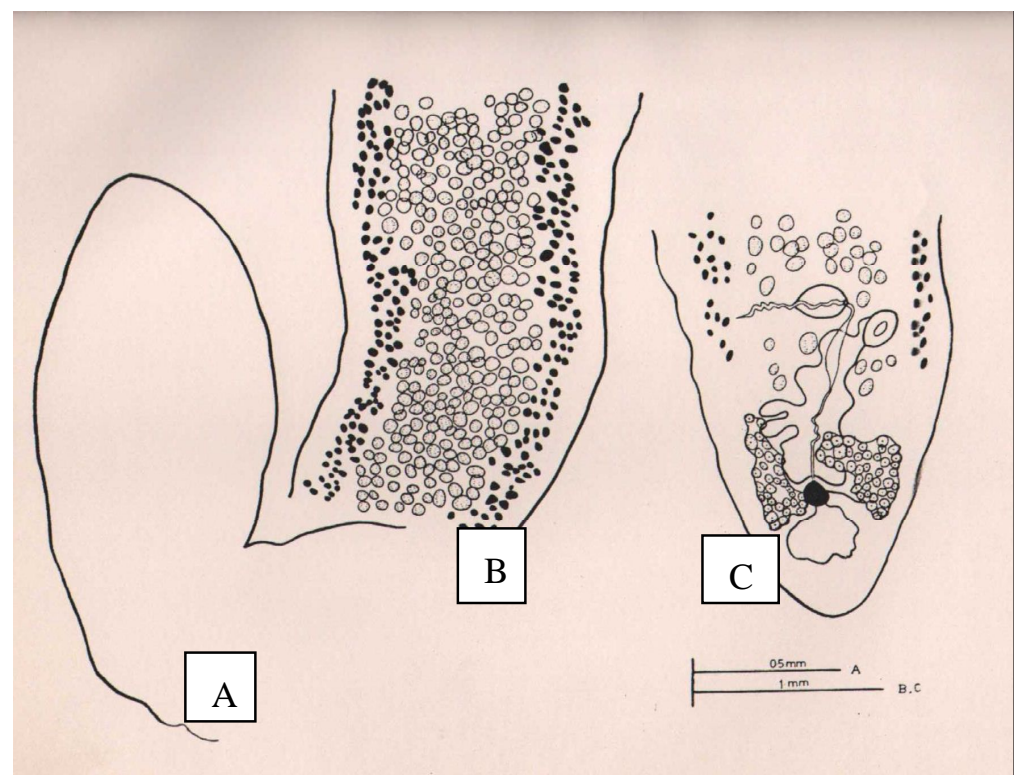

Figure 1. Lytocestus alii n.sp. A-Anterior region of the worm, B-Middle region of the worm and C-Posterior region of the worm (all measurements are in micron i.e. $\mu$ )

The uterus is a wide, convoluted tube, coiled, coils near each other transversely and antero-posteriorly situated, opens separately by a uterine pore. It measures 3.045 in length and $0.075-0.0425$ in breadth. The uterine pore is large, oval, with thick border, obliquely situated and measures $0.242 / 0.151$ in length and breadth. The ootype is large, oval, situated posterior to the isthmus and measures $0.148 / 0.151$ in length and breadth. The vitellaria are follicular, oval in shapes smaller in size than testis, sub-corticular in position. Lateral to testes, preovarian; extend laterally upto the base of the head, arranged in 3-4 rows and measure 0.037/0.022 to 0.090/0.068 in length and breadth respectively (Fig. 1, A, B and C).

\section{Discussion}

The worm under discussion in having the length of body 4.805, width of body $0.674-1.484$, testes 580-590 in number, arranged in 9-11 rows and ovarian follicles 32-39 in number, differs from L. adhaerens which is having the body elongated, tapering anteriorly; scolex undifferentiated, testes in broad median field of preuterine medulla, vas deferens convoluted, leading in to compact parenchymatous mass, not sharply demarcated from surrounding and containing dorsoventral muscle fibres; cirrus pouch with strongly muscular wall, opening in to deep narrow midventral pit; ovary bilobed with lateral lobes, outside of inner longitudinal muscle sheath; vitellaria surrounding inner longitudinal muscle sheath; vitellaria surrounding inner longitudinal muscle sheath in testicular zone, uterus looped behind shell gland and then closely coiled between ovary and male terminalis and vagina provided with a layer of accompanying cells, opening midventrally, directly behind cirrus.

The present worm differs from L. indicus which is having the length of the body 27-40; testes 230-270 in number, rounded, extending up to cirrus sac, some lateral to the same; cirrus pouch oval, vasdeferens followed by ductus ejaculatoreous, ovary with numerous follicles, connected by bag pipe shaped isthmus, receptaculum seminis absent and vitellaria small, 
corticular, rounded, in 2-3 rows, on each lateral side.

The present cestode differs from L.birmanicus which is having is having the length of the body of the worm 10-10, long neck, testes medullary, extending upto genital pore (0.01-0.018 $\mathrm{x}$ 0.01-0.13); cirrus pouch medullary in position, ovary wing-like, with numerous follicles; a number of loose cells, the most anterior loop reaching the space between the two genital openings and the vitellaria upto the uterovaginal pore (in the size of vitelline follicles)

The worm under discussion differs from L. alestesi which is having the length of the worm 10.5 , testes more of less spherical (0.050-0.070x0.040-0.060); cirrus pouch oval, in medullary region; ovary bilobed, to the posterior of the worm; uterus is very short, lies in loose coils and vitellaria extends from short distance behind the most anterior testes, up to the anterior tips of the horns of the ovary, but not beyond them.

The present form differs from L. longicollis which is having the length of the body of the worm 10.8-20.0, neck testes 105-140 in number, in two layers spherical, broad, oval; ' $\mathrm{H}$ ' shaped, corticular, with closely packed follicles, receptaculum seminis oval slightly anterior to isthmus and vitellaria large, corticular, round, all around testes, extending from the base of the neck to the anterior tip of the ovary, in 1-2 rows, on each lateral side.

The present worm differs from L.filliformis which is having the testes numerous, large, round, in central medulla; cirrus pouch small, bent between the concavity of the ovarian lobes; ovary bilobed small, each lobes consisting of 7-11, separate, large follicles, connected by a very big spindle shaped isthmus, near posterior region of the worm; vagina short, wide, a thick tube; vaginal pore large, with thick border, near isthmus; uterus convoluted, tubular, preovarian, with small and large convolutions, opens by uterine pore, anterior to cirrus pouch; uterine pore oval, large with thick border and vitellaria numerous follicular, large rounded, all around the testicular zone and medullary parenchyma.

The present tapeworm differs from L. thapari n.sp.(described earlier) which is having the length of the body of the worm, 13-12, width of body 0.81-1.9, testes 480-500 in number, arranged in 8-12 rows and ovarian follicles 30-31 in number, cirrus oblong in shape, obliquely placed, vas-deferens coiled, extends, extends anteriorly, ootype large, reniform receptaculum seminis oval in shape.

The characters discussed above justify the erection of a new species for these worms and hence the name L. alii n.sp. is proposed, after Prof. Syed Mehdi Ali, Ex-Professor and Head, Department of Zoology, Marathwada University, Aurangabad, M.S. who has contributed a lot in our knowledge of Helminthology.

\section{Type species: Lytocestus alii n.sp.}

Host: Clarias batrachus Bleeker, 1862.

Habitat: Intestine

Locality: Amravati, M.S. India. 


\section{References}

Cohn, (1908). Die. Amatomiaeines neuun fischeestoden. Central. Bakt. Parasitenk, 46, 134-139. Rivista Di Parasit, VIII (1), 19-22.

Furhmann, O. and J. G. Bear. (1925). Zoological results of the third Tanganyika Expedition conducted by Dr.W.A. Cunnigton, 1904-1905. Report on the Cestoda. Proceedings of the Zoological Society of London. 79-100.

Furtado, J. I. (1963). A new caryphyllaeid cestode, Lytocestus parvulus sp. Nov. from a Malayan cat fish. Annal and Magazine of Natural History (Ser B), 6, 93-106. http://dx.doi.org/10.1080/00222936308651329

Gupta, S. P. (1961). Caryophyllaeids (Cestoda) from fresh water fishes of India. Proceedings of the Helminthological Society of Washington, 28, 38-50.

Hunter, G. W. (1927). Studies on the Caryophyllaeidae of North America. Illin. Biol. Monogr., 11, 1- 86.

Jadhav, B. V., and A. V. Ghavane, (1991). Two new cestode from Caryophylleidae at Aurangabad. Ind. J. Inv. Zoo. And Aqua. Biol., 3(1), 28-31.

Kadam, M. N., C. J. Hiware, and B. V. Jadhav. (1998). On a new Caryophyllid cestode of genus Lytocestus Cohn, 1908 from Clarias batrachus. Dr. B. A. M. Uni. Aurangabad J. of Sci., 29(6), 143-148.

Khadap, R. M. B. V. Jadhav, and N. V. Suryavanshi. (2004). A New Species of the Genus Lytocestus (Cohn, 1908), from Clarias batrachus at Aurangabad. Nat. J. of Life Sciences, $1(2), 413-416$.

Kolpuke, (1999). On a new species if the genus Lytocestus Cohn, 1908 (Cestoda Caryphyllidea) from Wallago attu from Terna river at Aurad, India. Utt. Pra. J. Zoo., 19(1), 93-95.

Lynsdale, J. A. (1956). On two new species of Lytocestus from Burma and Sudan respectively. J. Helm., 30(2-3), 87-96. http://dx.doi.org/10.1017/S0022149X00033022

Mackiewicz, J. S. (1962). Systematic position of Caryophyllaeus fuhrmani Szidat, 1937 and Lytocestus alestesi Lynsdale, 1956 (Cestoidea: Caryophyllaeidea), Revue Swisse de Zoologie, 69, 729-735.

Mehra, H. R. (1930). On a new species of Caryophyllid of Muller from Kashmir with remarks on Lytocestus indicus (Moghe, 1925). Proc. 17. Ind. Sci. Congr. 247.

Moghe, M.A. (1925). Caryophyllaeus indicus n. sp. (Cestoda) from the catfish Clarias batrachus (L) Parasitology, 17, 232-335. http://dx.doi.org/10.1017/S0031182000004637

Patil, D. N., and B. V.Jadhav. (2002). On a new caryophyllid cestode of the genus Lytocestus Cohn, 1908, from Clarias batrachus. Ind. J. Hel. (N.S.), 20, 45-48. 
Pawar, S. B., and Shinde, G. B (2002). A new species Lytocestus batrachusae n.sp (Cotyloda- Lytocestidae) From Clarias batrachus at Aurangabad India. Riv. Di. Para., XIX (LXIII)(2), 153-156.

Poonam. (2007). On a new species of the genus Lytocestus (Caryophyllidea-Lytocestidae) from Clarias batrachus. Proc. Zool. Soc. Of India, 6(1), 77-81.

Poonam. (2007). On Lytocestus bokaronensis n. sp.(Caryophyllidea: Lytocestidae) for Clarias batrachus. Proc. Zool. Soc. of India, 6(2), 73-78.

Ramadevi, P. (1973). Lytocestus longicollis sp. Nov. (Cestoda: Caryophylliaeda), from cat fish. Clarias batrachus in India. J. Hel., 47, 415-420. http://dx.doi.org/10.1017/S0022149X00027437

Sawarkar, B. W., and G. B. Kale. (2012). Proceedings of the National Conference on Recent Trends in Biosciences, organized by G.S. Science, Arts and Commerce College, Khamgaon Dist. Buldana (M.S.), 341-347.

Shinde, G. B., and A. N. Phad. (1988). On a new cestode Lytocestus marathwadensis from fresh water fish. Riv. Di. Para., 47(2), 295-298.

Shinde, G. B., and R. A. Deshmukh. (1980). On a new cestode Senga khami n.sp (Cestoda: Ptychobothriidae) from a freshwater fish. Indian J. Zool., 8(1), 28-32.

Surayawanshi, S. G., D. K. Maske, G. B. Shinde, and H. K. Bhagwan. (2010). A new tapeworm Lytocestus shindei n.sp. (Cestoda: Lytocestidae) from Calrias batrachus at Rahuri Dist. Ahmednagar (M.S.) Life sci. Bulletin, 1, 148-150.

Tandon, V., R. Chakravarty, and B. Das. (2005). Four new species of the genus Lytocestus (Caryophyllidea: Lytocestidae) from Edible Cat fishes in Assam and Meghalaya, India. Jour. of Parasitic Diseases, 29(2), 131-142.

Wardle, R A., and J. A. Mcleod. (1952). The Zoology of tapeworms. University of Minnesota Press, Minneapolis, pp 780.

Wardle, R A., J A. Mcleod, and S. Radinovsky. (1974). Advances in the zoology of Tapeworm, 1950 - 1970. University of Minnesota Press, Minneapolis, 1-274.

Woodland, W. N. F. (1923). On some remarkable new forms of Caryophyllaeidae from the Anglo-Egyptian Sudan and a revision of the families of the Cestodaria. Quart. J. Micr. Sc., 67, 435-472.

Woodland, WNF. (1926). On the genera and possible affinities of the caryophyllaeidae: a reply to Drs. Furhrmann O. and Baer JG. Proc. of the Zoo. Soc. of London, 1926, 49-69.

Yamaguti, S. (1959). The cestode of vertebrates. In: Systema helminthum. Vol. 2. New York: Interscience: $860 \mathrm{pp}$. 


\section{Copyright Disclaimer}

Copyright reserved by the author(s).

This article is an open-access article distributed under the terms and conditions of the Creative Commons Attribution license (http://creativecommons.org/licenses/by/3.0/). 